\title{
Main Risk Factors for Mortality After Cardiovascular Interventions in Newborns with Critical Congenital Heart Diseases
}

\author{
Kritik Konjenital Kalp Hastalıklı Yenidoğanlarda Kardiyak Girişim Sonrası \\ Mortaliteyi Etkileyen Ana Risk Faktörleri
}

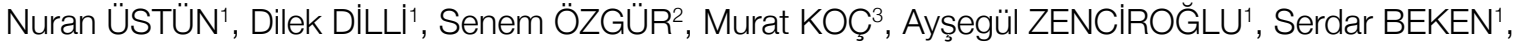 \\ Nurullah OKUMUȘ ${ }^{1}$
}

${ }^{1}$ Dr. Sami Ulus Maternity and Children Research and Training Hospital, Department of Neonatology, Ankara, Turkey

${ }^{2}$ Dr. Sami Ulus Maternity and Children Research and Training Hospital, Department of Pediatric Cardiology, Ankara, Turkey

${ }^{3}$ Dr. Sami Ulus Maternity and Children Research and Training Hospital, Department of Cardiovascular Surgery, Ankara, Turkey

\begin{abstract}
Objective: It was aimed to define the main risk factors that affect mortality in infants with critical congenital heart disease (CHD).

Material and Methods: We analyzed data from 105 infants with critical $\mathrm{CHD}$ underwent cardiovascular intervention at a tertiary neonatal intensive care unit (NICU) between September 2010 and January 2012. Demographic data, clinical findings (before and after intervention), type of intervention, and intervention risk score according to Risk Adjustment in Congenital Heart Surgery (RACHS-1) classification were evaluated.

Results: The mean age at cardiovascular intervention was $15.2 \pm 11.8$ days. Transcatheter interventions were performed in 29 patients (27.6\%). Seventy-six patients (72.4\%) underwent cardiovascular surgery. At post-interventional period, the rates of low cardiac output, pneumonia, and sepsis were significantly higher among patients underwent surgical intervention. Length of NICU stay was also longer among them. Overall mortality rate was $35.2 \%(n=37)$. Mortality was significantly lower in infants underwent transcatheter intervention. Univariate analyses showed that nonsurvivors differed from survivors in terms of gestational age, prematurity, the presence of associated disorder, pre-interventional need of mechanical ventilation, need of inotropic support, the presence of pulmonary hypertension and sepsis, requirement of cardiovascular surgery, age at intervention, and RACHS-1 score. Multivariate analysis showed that higher RACHS-1 score was associated with mortality (OR: $4.5,95 \% \mathrm{Cl}(1.5-13.1), \mathrm{p}=0.005)$ while higher gestational age was a preventive factor (OR: 0.6, $95 \% \mathrm{Cl}(0.5-0.9), \mathrm{p}=0.01)$.
\end{abstract}

Conclusion: Our study indicates that lower gestational age and severity of the disease seem to be most possible risk factors for mortality among infants with critical CHD.

Key Words: Congenital heart disease, Newborn, Prematurity

\section{ÖZET}

Amaç: Kritik konjenital kalp hastalıklı $(\mathrm{KKH})$ yenidoğanlarda girişim sonrası mortaliteyi etkileyen risk faktörlerinin belirlenmesi amaçlandı.

Gereç ve Yöntemler: Üçüncü düzey bir yenidoğan yoğun bakım ünitesinde (YYBÜ) Eylül 2010-Ocak 2012 tarihleri arasında izlenen ve girișim uygulanan kritik KKH tanılı 105 yenidoğan incelendi. Hastaların demografik verileri, girișim öncesi ve sonrası klinik bulguları, girişim tipi, Doğuştan Kalp Cerrahisi için Risk Ayarlanması sınıflamasına göre girişimsel risk skoru (Risk Adjustment in Congenital Heart Surgery; RACHS-1) ile ilgili veriler kaydedildi.

Bulgular: Kardiyak girişim sırasında ortalama yaş 15.2 11.8 gündü. Transkateter girişim 29 (\%27.6) hastada uygulandı. Toplam 76 hastaya (\%72.4) kardiyak cerrahi girișim yapıldı. Girişim sonrası dönemde düşük kardiyak debi, pnömoni ve sepsis görülme sıkliğı cerrahi girișim yapılan olgularda daha yüksekti. Bu hastalarda YYBÜ kalış süresi de daha uzundu. Mortalite oranı \%35.2 ( $n=37$ ) olarak bulundu. Transkateter girişim yapılan hastalarda mortalite daha düşüktü. Univaryant analizde ölen hastalarda gebelik haftasının daha düşük, prematürite oranının daha fazla, eșlik eden hastalık sıkığının daha yüksek, girişim öncesi mekanik ventilatörde kalma oranı, inotrop desteği, pulmoner hipertansiyon ve sepsis oranının daha fazla, cerrahi girişim gereksiniminin daha çok, girişim sırasındaki yaş ve RACHS-1 skorunun daha yüksek olduğu saptandı. Çoklu regresyon analizinde RACHS-1 skorunun yüksek olmasının mortalite ile ilişkili olduğu (Odds oranı: 4.5, \%95 GA (1.5-13.1), p=0.005), gebelik yaşının büyük olmasının ise koruyucu bir faktör olduğu dikkati çekti (Odds oranı: 0.6, GA( \%95) (0.5-0.9), $p=0.01)$. 
Sonuç: Bu çalışmada cerrahi girişim gereken kritik KKH'lı yenidoğanlar arasında mortalitenin yüksek olduğu, Özellikle gebelik haftasının düşük, RACHS-1 skorunun ise yüksek olmasının mortalite riskini artırdığı sonucuna varıldı.

Anahtar Sözcükler: Konjenital kalp hastalığı, Yenidoğan, Prematürite

\section{INTRODUCTION}

The reported total congenital heart disease (CHD) birth prevalence has increased substantially over time, from 0.6 per 1.000 live births in 1930 to 9.1 per 1,000 live births after 1995 (1). The recent incidence of CHD in the neonatal intensive care unit (NICU) has been reported as 3.7\% in full-term and 6.8\% in pre-term infants (2). In Turkey, every year 12,000 babies born with $\mathrm{CHD}$ and the prevalence rate is comparable to developed countries (7.7\%) (3). Nearly half (48.1\%) of deaths due to CHD occur during infancy (4).

Significant technologic advances have improved outcomes in neonatal cardiac surgery over the past three decades. However, outcomes might be different in developing countries because of the infrastructure limitations (5). Many factors such as late presentation of cases, associated co-morbid conditions, understaffing of units and limited resources contribute to suboptimal outcome in neonates with $\mathrm{CHD}$ who undergo cardiac intervention (6).

With advance in preoperative, surgical, and postoperative care, cardiac interventions for critical CHD have been more performed on infants to restore normal hemodynamic stability during this period. However, these interventions may result in many complications even mortality $(7,8)$.

In this study, it was aimed to present our preliminary results of neonatal cardiovascular interventions and to discuss the risk factors that affect mortality.

\section{MATERIAL and METHODS}

We analyzed data from 105 patients with critical CHD, less than 45 days, underwent cardiovascular intervention at a tertiary neonatal intensive care unit (NICU) of a reference hospital between September 2010 and January 2012. In our NICU, the patients with CHD have been followed-up in consultation of pediatric cardiologists and cardiovascular surgeons. Most of our patients are referred to us from other hospitals, although around a quarter are inborn. Sometimes cardiovascular interventions may be performed on beyond one month of age because of wrong/late diagnosis of CHD in another center, delayed transfer of the patients, understaffing of the departments, and clinical condition of the patients.

Critical $\mathrm{CHD}$ is defined as a $\mathrm{CHD}$ requiring surgical or transcatheter cardiac intervention (9). Patent ductus arteriosus ligation and pacemaker placement were excluded. Data were obtained from the computerized patient record system of the hospital.
Demographic data of each patient (gestational age, birthweight, gender, age at diagnosis, echocardiography assessment, the presence of heterotaxy syndrome and chromosomal abnormality) were noted. The clinical findings before surgical or transcatheter cardiac intervention (the need for mechanical ventilation, inotropic support, and presence of pulmonary hypertension, arrhythmia, sepsis, kidney and liver dysfunction) were also receorded. Age at intervention, type of intervention (surgical or transcatheter), and intervention risk score according to Risk Adjustment in Congenital Heart Surgery (RACHS-1) classification were evaluated. RACHS-1 is a validated risk adjustment method that groups cardiac surgical procedures with similar expected in-hospital mortality rates into six predefined risk categories, in which category 1 has the lowest risk for death (e.g., secundum atrial defect closure), and category 6 has the highest risk for death (e.g., stage 1 Norwood surgery) (10). The primary outcome variable was in-hospital mortality for patients undergoing surgical or transcatheter cardiac intervention. Complications after surgical or transcatheter cardiac intervention were evaluated as secondary outcome.

Informed consent has been obtained from the parents of the patients both prior to hospitalization and before any interventions in our unit. This was not an experimental study and approved by Ethics Review Committee.

Data were recorded by using SPSS 15.0 (Chicago, IL, USA). Descriptive analyses were performed. Mean (SD) or Median (IQR) values were given according to distribution of the data. Differences among the groups were tested using Student's $t$ test or Mann Whitney $U$ test, as appropriate. Chi-square test was used for categorical data. Multivariate analysis was used to define the factors associated with higher mortality risk in infants underwent cardiac intervention. Gestational age, age at diagnosis of $\mathrm{CHD}$, the need of mechanical ventilation, the presence of sepsis at pre-interventional period, age at intervention, the type of intervention, RACHS-1 score, and development of low cardiac output at post interventional period were assigned as independent variables. The level of significance was set at 0.05 in all comparisons.

\section{RESULTS}

During the study period, a total of 105 patients underwent surgical or transcatheter cardiac intervention. Most were out-born and transferred from another health service. The demographical and clinical characteristics of the subjects are summarized in Table I. 
The most common diagnoses were coarctation of aorta (AoC), pulmonary atresia (PA) and transposition of great arteries (TGA). Types of the CHDs are shown in Table II.

Congenital heart pathologies were associated with situs anomalies in 15 patients. These were right atrial isomerism $(n=12)$, left atrial isomerism $(n=1)$, and situs inversus totalis $(n=2)$. Eight cases had major genetic disorders including Trisomy 21 $(n=4)$, Trisomy $18(n=2)$, and Di George syndrome $(n=2)$.

Prostaglandin E1 (PGE1) was needed in 79 cases $(75.2 \%)$ at pre-interventional period. The mean age at surgical or transcatheter cardiac intervention was $15.2 \pm 11.8$ days. The most common reasons of delay for surgical or transcatheter cardiac interventions were the presence of sepsis on admission, delayed transportation of the patients, and inadequate staffing.

Transcatheter interventions were performed in 29 patients (27.6\%); none of them needed surgery. Seventy-six patients (72.4\%) underwent cardiovascular surgery. The most common surgeries were modified Blalock Taussig shunt (mod B-T shunt), coarctation repair, and pulmonary banding (Table III).

The most common complications observed at postinterventional period were listed in Table IV. The rates of low

Table I: The demographical and clinical characteristics of the study patients.

\begin{tabular}{|c|c|}
\hline Patient Characteristics & $n=105$ \\
\hline Prenatal diagnosis of CHD. $n(\%)$ & $7(6.6)$ \\
\hline Out-born patients, n (\%) & $90(85.7)$ \\
\hline Gestational age (weeks), mean \pm SD & $38.8 \pm 2.0$ \\
\hline Prematurity (<37 weeks of gestational age) & $15(14.2)$ \\
\hline Birth weight $(g)$, mean \pm SD & $3002 \pm 571$ \\
\hline Male sex, $n(\%)$ & $65(61.9)$ \\
\hline Age at diagnosis of CHD (d), median (IQR) & $4(2-11)$ \\
\hline \multicolumn{2}{|l|}{$\begin{array}{l}\text { UyuClinical variables at pre-interventional } \\
\text { period }\end{array}$} \\
\hline Need of mechanical ventilation, $\mathrm{n}(\%)$ & $25(23.8)$ \\
\hline Need of inotropic support, n (\%) & $14(13.3)$ \\
\hline Pulmonary hypertension, n (\%) & $41(39)$ \\
\hline Arrhythmias, $\mathrm{n}(\%)$ & $13(12.4)$ \\
\hline Renal failure, $\mathrm{n}(\%)$ & $5(4.7)$ \\
\hline Peritoneal dialysis & $3(2.8)$ \\
\hline Clinical/proven sepsis, n (\%) & $12(11.4)$ \\
\hline Liver dysfunction, n (\%) & $13(12.4)$ \\
\hline \multicolumn{2}{|l|}{ Associated disorders } \\
\hline Situs anomalies & $15(14.2)$ \\
\hline Major genetic disorders & 7 (6.6) \\
\hline $\begin{array}{l}\text { Length of hospital stay (days), } \\
\text { median (IQR) }\end{array}$ & $21(15-34.5)$ \\
\hline Mortality, n (\%) & $37(35.2)$ \\
\hline
\end{tabular}

${ }^{*}$ Congenital heart disease cardiac output, pneumonia, and sepsis were significantly higher among patients underwent surgery. Length of NICU stay was longer among them [surgery: 30 (18-38.5) days vs. transcatheter: 15 (12-18.5) days, $p=0.001]$.

Table II: The types of congenital heart diseases in study patients.

\begin{tabular}{|l|r|r|}
\hline & $\mathbf{n = 1 0 5}$ & \% \\
\hline Left heart obstruction & & \\
\hline Coarctation of aorta & 35 & 33,3 \\
\hline Aortic interruption & 5 & 4,7 \\
\hline Aortic valve stenosis & 4 & 3,8 \\
\hline Hypoplastic left heart syndrome & 3 & 2,8 \\
\hline Mitral valve atresia & 1 & 0,9 \\
\hline Left ventricle hypoplasia & 1 & 0,9 \\
\hline Right heart obstruction & & \\
\hline Pulmonary atresia & 19 & 18 \\
\hline Critical pulmonary stenosis & 9 & 8,5 \\
\hline Fallot type pulmoner atresia & 4 & 3,8 \\
\hline Tricuspid atresia & 4 & 3,8 \\
\hline Mixing pathology & & \\
\hline Transposition of great arteries & 14 & 13,3 \\
\hline Truncus arteriosus & 4 & 3,9 \\
\hline Double outlet right ventricle & 1 & 0,9 \\
\hline Other & & 0,9 \\
\hline Ventricular septal defect & 1 & \\
\hline
\end{tabular}

Table III: The types of cardiac interventions and intervention-specific hospital mortality for the study patients.

\begin{tabular}{l|c|c}
\hline Type of intervention & $\begin{array}{c}\text { Study } \\
\text { patients } \\
(n=105)\end{array}$ & $\begin{array}{c}\text { Mortality } \\
(n=37)\end{array}$ \\
\hline
\end{tabular}

Transcatheter intervention $(\mathrm{n}=\mathbf{2 9}), \%$

Balloon dilatation of coarctation of aorta

9 (8.5) $\quad 3(8.1)$

Atrial septostomy

7 (6.6)

$0(0)$

Balloon dilatation of aortic valve

4 (3.8)

$0(0)$

Balloon dilatation of pulmonary valve

$0(0)$

Cardiovascular surgery $(n=76), \%$

Modified Blalock-Taussig shunt

$29(27.6) \quad 10(27)$

Coarctation repair + pulmonary

banding

16 (15.2) $8(21.6)$

Coarctation repair

$10(9.5)$

2 (5.4)

Arterial switch

$6(5.7)$

$3(8.1)$

Norwood surgery-Stage 1

3 (2.8)

$3(8.1)$

Aortic interruption repair

4 (3.8)

$3(8.1)$

Repair of truncus arteriosus

4 (3.8)

$4(10.8)$

Pulmonary banding
$4(3.8)$ 
Table IV: Complications observed at post-interventional period.

\begin{tabular}{|l|c|c|c|}
\hline Complication & $\begin{array}{c}\text { Catheterization } \\
\mathbf{n = 2 9 ( \% )}\end{array}$ & $\begin{array}{c}\text { Cardiovascular } \\
\text { surgery } \mathbf{n = 7 6}(\%)\end{array}$ & P value \\
\hline Low cardiac output syndrome & $2(6.9)$ & $20(26.3)$ & 0.03 \\
\hline Pneumonia/ventilator associated pneumonia & $2(6.9)$ & $25(32.9)$ & 0.01 \\
\hline Clinical/proven sepsis & $1(3.4)$ & $17(22.4)$ & 0.02 \\
\hline Renal failure & $4(13.7)$ & $12(15.8)$ & 0.68 \\
\hline Peritoneal dialysis & $1(3.4)$ & $6(7.9)$ & 0.70 \\
\hline Liver dysfunction & $3(10.3)$ & $14(18.4)$ & 0.47 \\
\hline Thrombosis & $5(17.2)$ & $10(13.2)$ & 0.75 \\
\hline Intracranial hemonhage (>grade 2) & $0(0)$ & $8(10.5)$ & 0.06 \\
\hline Heart failure & $1(3.4)$ & $12(15.8)$ & 0.10 \\
\hline Arrythmias & $0(0)$ & $5(6.6)$ & 0.31 \\
\hline
\end{tabular}

Overall mortality rate was $35.2 \%$ ( $n=37)$. Intervention specific hospital mortality rates are listed in Table III. Mortality was significantly lower in infants treated with transcatheter intervention (Table V). Three of 29 patients (10.3\%) who underwent balloon dilatation of AoC died. One of them was a 32 weeks of gestational age premature baby with AoC along with isthmus hypoplasia, left ventricular dysfunction and partial pulmonary venous connection abnormality. Other two patients were term newborns with AoC, severe isthmus hypoplasia and pulmonary hypertension. Twenty four of them (64.8\%) died due to acute postoperative complications such as low cardiac output syndrome $(n=20)$ and sudden cardiac arrest $(n=4)$ within the first 48 hours of the surgical intervention. At follow-up, heart failure $(n=5)$, respiratory insufficiency $(n=4)$, and sepsis $(n=4)$ were the causes of mortality.

Univariate analyses showed that there were significant differences between the survivors and nonsurvivors according to gestational age, prematurity, the presence of associated disorder, pre-interventional need of mechanical ventilator, use inotropic support, presence of pulmonary hypertension and sepsis, undergoing cardiovascular surgery, age at intervention, and RACHS-1 score.

Multivariate analysis was used to define the risk factors associated with mortality. It was found that higher RACHS-1 score was associated with mortality (OR: $4.5,95 \% \mathrm{Cl}$ (1.513.1), $p=0.005)$. Higher gestational age was a preventive factor for it (OR: 0.6, 95\% Cl (0.5-0.9), $p=0.01$ ).

\section{DISCUSSION}

In this article, we report the early outcomes of cardiac interventions in a cohort of 105 consecutive neonates with critical $\mathrm{CHD}$. The infrastructure limitations that exist in our $\mathrm{NICU}$ are typical of centers performing neonatal cardiac interventions in the developing world.
Delay in performing intervention puts the CHD infants at a greater risk for infections and organ dysfunction (11). Finally, these infants are more likely to develop problems, in addition to their cardiac diseases. In our study, post-interventional complications and mortality were evaluated as outcomes. The rates of pre and post-interventional problems were higher among nonsurvivors. Probably, pre-interventional problems caused to delay for intervention in these infants.

It was reported that transcatheter intervention had mortality rate less than $1 \%$ in experienced institutions. It could be as high $3.7-7.7 \%$ and associated cardiac pathologies might increase mortality $(12,13)$. Ergul et al. (14) showed that isthmus hypoplasia and pulmonary hypertension were risk factors for AoC dilatation during neonatal period. The newborns, especially premature babies, undergoing balloon dilatation of AoC were at high risk for mortality (15). Our study showed that the number of complications were lower in infants who underwent transcatheter intervention. As expected NICU stay was also shorter among them and a similar trend was hence obtained in mortality.

Some recent research demonstrated both improved survival and reduced morbidity in prenatally diagnosed infants presenting to cardiac intensive care units compared to those with a postnatal diagnosis $(16,17)$. However, Lim et al. (18) reported that prenatal diagnosis did not affect overall survival despite facilitated care in patients with isomerism. In our study, of 105 patients, only seven had prenatal diagnosis. Mortality rate was not lower in these patients compared to others without prenatal diagnosis. However, it is fact that prenatal diagnosis can be useful for better management of $\mathrm{CHD}$ patients.

It is well known that preterm delivery is associated with adverse outcomes. Pappas et al. (19) assessed the mortality, morbidity, and early childhood outcomes of $<1000 \mathrm{~g}$ infants with isolated $\mathrm{CHD}$ compared with infants with no congenital defects. The authors showed that adjusted risks of other short-term neonatal morbidities associated with prematurity were not significantly 
different. Risk of death or neurodevelopmental impairment (NDI) was greater for $<1000 \mathrm{~g}$ infants with $\mathrm{CHD}$. Cheng et al. (17) showed that delivery at 37 to 38 completed weeks of gestation was associated with more than twofold greater adjusted odds of patient hospital mortality and significantly greater morbidity compared with delivery at 39 to 40 completed weeks among neonates with CHD. Similarly, Costello et al. (20) reported that gestational age lower than 39 week is associated with mortality. In the current study, higher gestational age was a preventive factor for mortality.

Magliola et al. (9) reported a mortality rate of 19\% in neonatal cardiac surgery from Argentina in 5 year period. We found a high mortality rate in cardiac interventions (35.2\%). However,

Table V: Clinical characteristics of the patients related to the mortality.

\begin{tabular}{|c|c|c|c|}
\hline Variables & $\begin{array}{c}\text { Nonsurvivors } \\
\text { Nonsurvivors } \\
n=37 .(\%)\end{array}$ & Survivors & $\begin{array}{c}P \text { value } \\
n=68 .(\%)\end{array}$ \\
\hline Prenatal diagnosis of CHD, n (\%) & $2(5.4)$ & $5(7.4)$ & 0.7 \\
\hline Gestational age (wk), mean \pm SD & $37.8 \pm 2.2$ & $39.8 \pm 1.8$ & 0.006 \\
\hline Prematurity, n (\%) & $9(24.3)$ & $6(8.8)$ & 0.03 \\
\hline Birth weight (g), mean \pm SD & $2930 \pm 609$ & $3041 \pm 550$ & 0.3 \\
\hline Male sex, n (\%) & $23(62.1)$ & $42(61.7)$ & 0.4 \\
\hline Age at diagnosis of CHD, median (IQR) & $5(2-13)$ & $3(2-11)$ & 0.11 \\
\hline \multicolumn{4}{|l|}{ Clinical variables at pre-interventional period, $\mathbf{n}(\%)$} \\
\hline Need of mechanical ventilation & $14(37.8)$ & $11(16.2)$ & 0.01 \\
\hline Need of inotropic support & 9 (27.3) & $5(9.3)$ & 0.02 \\
\hline Pulmonary hypertension & $21(56.8)$ & $20(29.4)$ & 0.006 \\
\hline Arrythmias & $1(2.7)$ & $1(1.5)$ & 1.0 \\
\hline Renal failure & $7(18.9)$ & $6(8.8)$ & 0.1 \\
\hline Clinical/proven sepsis & & $4(5.9)$ & 0.01 \\
\hline Liver dysfunction & 7 (18.9) & $6(8.8)$ & 0.1 \\
\hline \multicolumn{4}{|l|}{ Complications at post-interventional period, n (\%) } \\
\hline Low cardiac output syndrome & $16(43.2)$ & $6(8.8)$ & 0.001 \\
\hline Pneumonia & 8 (21.6) & $19(27.9)$ & 0.63 \\
\hline Clinical/proven sepsis & $8(21.6)$ & $10(14.7)$ & 0.53 \\
\hline Renal failure & $9(24.3)$ & $6(8.8)$ & 0.06 \\
\hline Liver dysfunction & $10(27)$ & 7 (10.3) & 0.05 \\
\hline Thrombosis & $8(21.6)$ & 7 (10.3) & 0.19 \\
\hline Intracranial hemorrhage (>grade 2) & $3(8.1)$ & $5(7.4)$ & 1.0 \\
\hline Heart failure & $11(29.7)$ & $2(2.9)$ & 0,001 \\
\hline Arrythmias & $2(5.4)$ & $3(4.4)$ & 1.0 \\
\hline \multicolumn{4}{|l|}{ Associated disorders } \\
\hline Situs anomalie, n (\%) & $10(27)$ & $5(7.4)$ & 0.006 \\
\hline Chromosomal abnormality, n (\%) & $5(13.5)$ & $2(2.9)$ & 0.03 \\
\hline Age at intervention (days), median (IQR) & $15(10-28)$ & $11(11-19)$ & 0.001 \\
\hline \multicolumn{4}{|l|}{ The type of intervention } \\
\hline Catheterization & $3(8.1)$ & $26(38.2)$ & \\
\hline Cardiovascular surgery & $34(91.8)$ & $42(61.7)$ & 0.003 \\
\hline \multicolumn{4}{|l|}{ RACHS-1 category } \\
\hline $1-2$ & $5(13.5)$ & $34(50)$ & 0.0001 \\
\hline 3 & $13(35.1)$ & $26(38.2)$ & \\
\hline 4 & $16(43.2)$ & $8(11.7)$ & \\
\hline $5-6$ & $3(8.1)$ & 0 & \\
\hline Length of neonatal intensive care unit stay (d), median (IQR) & $18(11.5-35.5)$ & $25.5(17-34.2)$ & 0.09 \\
\hline
\end{tabular}


in Magliola et al.'s study (9), experience in cardiac surgery and advanced care (e.g., extracorporeal membrane oxygenation use) should be noticed. In another study from a developing country, Bakshi et al. (21) reported their mortality for all neonatal corrective and palliative cardiac surgical procedures as $8.8 \%$. In our study, mortality was particularly striking for corrective operations and this rate was higher than that of reported from the Bakshi et al.'s study. We should note that the authors excluded the patients with highly complex lesions, such as hypoplastic left heart syndrome and severe Ebstein anomaly. Excluding them will be expected to improve the outcomes reported in their study, as they also emphasized. Management of $\mathrm{CHD}$ with appropriate surgeries at proper time in developing countries is still a major challenge.

In a study from a developed country, evaluating 174 infants undergoing cardiac intervention, the authors reported that independent risk factors for mortality were a 5 min Apgar score $\leq 7$, need for pre-intervention mechanical ventilation, and RASCH-1 category $\geq 4$ or not assignable (17). Bakshi et al. (21) stated that the earlier period of surgical intervention, age of less than 7 days, need for preoperative antibiotics, and requirement of exchange transfusion for postoperative sepsis were predictors of mortality. According to our results, univariate analyses showed that there were significant differences between the survivors and nonsurvivors for gestational age, the presence of associated disorder, pre-interventional need of mechanical ventilator and inotropic support, presence of pulmonary hypertension and sepsis, undergoing cardiovascular surgery, RACHS-1 score and post-interventional low cardiac output syndrome and heart failure. However, in multivariate analysis only higher RACHS-1 score was shown to be associated with mortality while higher gestational age was a preventive factor.

It has been reported that situs anomalies with complex cardiac defects and the presence of immunologic dysfunction increases the risk for mortality $(18,22)$. We also observed that the rate of situs anomalies and chromosomal abnormality associated to CHD was higher among nonsurvivors. Major extra cardiac anomalies accompanied with chromosomal anomalies can explain higher mortality rate in this group.

The most reported other predictors of mortality in CHD patients are infectious complications (21). Although the rate of pre-interventional sepsis was higher among nonsurvivors, post-interventional sepsis rate did not differ between survivor and nonsurvivors.

There are some limitations resulting from the retrospective nature of our study. Furthermore, it is a single center based study, so a lot has to be taken into consideration before the results can be generalized. Another important limitation is the inclusion of all interventions such as interventional catheterization procedures; including these would be expected to improve the outcomes.

Our study indicates that currently our unit has a high mortality rate compared to other NICUs of different countries. The results of this study are of particular relevance to NICU staff planning to co-work with pediatric cardiovascular surgery on the road of being a newborn CHD center. Few published reports on the outcomes of NICU-CHD surgery are available from the developing world $(6,21,23,24)$. Improvement in outcomes with growing experience has been reported by other centers and is associated with the initial learning curve of new programs (25). Because of infrastructure limitations and some logistic problems, there are many challenges to establishing and maintaining a NICU-CHD surgery program in these countries.

Neonatal mortality in Turkey has declined substantially over the past 10 years, 26/1000 in 1998 and 10/1000 in 2009 (26). This indicates that maternal and neonatal health interventions have played a major role in decreasing neonatal mortality rate in our country. As neonatal and infant mortality from readily preventable conditions decrease, CHDs are likely to require increasing attention.

Currently, in Turkey, a total of 23 centers (6 public, 4 private and 13 university hospitals) deal with pediatric cardiovascular surgery. However, neonatal cardiovascular surgery could be performed only in one third of them $(27,28)$. On the other hand, there are geographic and socio-economic inequalities among people living in our country. Therefore, transportation of the CHD patients from a rural area to the cardiovascular surgery center can be problematic. In recent years, Ministry of Health of Turkey has taken important steps in increasing the number of the cardiovascular surgery centers and improving patient transport. However, there is still need to new well equipped cardiovascular surgery centers experienced in the management of neonatal $\mathrm{CHD}$ patients.

The common problems of the developing countries are inexperienced cardiac team, inadequate staffing, limited infrastructure and resources. These problems can only be solved by determined health policies and increased experience of the centers.

\section{CONCLUSIONS}

In this study, we reported our local data for the first year experience in neonatal cardiovascular surgical or transcatheter intervention and compared the results with other institutions. With increasing experience, neonatal cardiac surgery may be performed with better outcomes in developing countries that have limited infrastructure and resources. 


\section{REFERENCES}

1. Van der Linde D, Konings EE, Slager MA, Witsenburg M, Helbing WA, Takkenberg JJ, et al. Birth prevalence of congenital heart disease worldwide: A systematic review and meta-analysis. J Am Coll Cardiol 2011;58:2241-7.

2. Cho SY, Oh JH, Lee JH, Lee JY, Lee SJ, Han JW, et al. Recent incidence of congenital heart disease in neonatal care unit of secondary medical center: A single center study. Korean J Pediatr 2012;55:232-7.

3. Bașpinar O, Karaaslan S, Oran B, Baysal T, Elmaci AM, Yorulmaz A. Prevalence and distribution of children with congenital heart diseases in the central Anatolian region, Turkey. Turk $\mathrm{J}$ Pediatr 2006;48:237-43.

4. Gilboa SM, Salemi JL, Nembhard WN, Fixler DE, Correa A. Mortality resulting from congenital heart disease among children and adults in the United States, 1999 to 2006. Circulation 2010;122:2254-63.

5. Tchervenkov Cl, Jacobs JP, Bernier PL, Stellin G. The improvement of care for paediatric and congenital cardiac disease across the World: A challenge for the World Society for Pediatric and Congenital Heart Surgery. Cardiol Young 2008;Suppl 2: 63-9.

6. Saxena A, Sharma M, Kothari SS, Juneja R, Reddy SC, Sharma $R$, et al. Prostaglandin E1 in infants with congenital heart disease: Indian experience. Indian Pediatr 1998;35:1063-9.

8. Connor JA, Gauvreau K, Jerkins KJ. Factors associated with increased resource utilization for congenital heart disease. Pediatrics 2005;116:689-95.

9. Magliola R, Althabe M, Moreno G, Lenz AM, Pilan ML, Landry L, et al. Cardiac surgical repair in newborns: Five years' experience in neonatal cardiovascular surgery. Arch Argent Pediatr 2009;107: 417-22.

10. Jenkins KJ, Gauvreau K, Newburger JW, Spray TL, Moller JH, lezzoni LI. Consensus-based method for risk adjustment for surgery for congenital heart disease. J Thorac Cardiovasc Surg 2002;123:110-8.

11. Panni RZ, Ashfaq A, Amanullah MM. Earlier surgical intervention in congenital heart disease results in better outcome and resource utilization. BMC Health Serv Res 2011;11:353.

12. Kreutzer J. Transcatheter intervention in the neonate with congenital heart disease. Clin Perinatol 2001;28:137-57.

13. Tokel K, Ekici E, Kutsal A, Ikizler C. Aort koarktasyonunda balon anjiyoplasti: İlk deneyimler. Türk Kardiyol Dern Arş 1997;25:287-92.

14. Ergül $Y$, Nişli K, Dindar A, Eker Ömeroğlu R, Aydoğan U. The comparison a 16-year follow-up results of balloon angioplasty for aortic coarctation in children of different age groups: A single-center experience]. Anadolu Kardiyol Derg 2011;11:336-42.

15. Beekman RH. Coarctation of the aorta. In: Allen HD, Gutgesell HP, Clark EB, Driscoll DJ (eds). Moss and Adams' Heart Disease in Infants, Children, and Adolescents. 6th ed. Philadelphia: Lippincott Williams \& Wilkins, 2001:988-1010.
16. Guerchicoff M, Marantz P, Infante J, Villa A, Gutiérrez A, Montero G. Assessing the impact of early diagnosis of congenital heart disease. Arch Argent Pediatr 2004;102: 445.

17. Cheng HH, Almodovar MC, Laussen PC, Wypij D, Polito A, Brown $\mathrm{DW}$, et al. Outcomes and risk factors for mortality in premature neonates with critical congenital heart disease. Pediatr Cardiol 2011;32:1139-46.

18. Lim JS, Mc Crindle BW, Smallhorn JF, Golding F, Caldarone CA, Taketazu M, et al. Clinical features, management, and outcome of children with fetal and postnatal diagnoses of isomerism syndromes. Circulation 2005;112:2454-61.

19. Pappas A, Shankaran S, Hansen NI, Bell EF, Stoll BJ, Laptook $\mathrm{AR}$, et al. Outcome of extremely preterm infants $(<1,000 \mathrm{~g})$ with congenital heart defects from the national institute of child health and human development neonatal research network. Pediatr Cardiol 2012;33:1415-26.

20. Costello JM, Polito A, Brown DW, McElrath TF, Graham DA, Thiagarajan RR, et al. Birth before 39 weeks' gestation is associated with worse outcomes in neonates with heart disease. Pediatrics 2010;126:277-84.

21. Bakshi KD, Vaidyanathan B, Sundaram KR, Roth SJ, Shivaprakasha K, Rao SG, et al. Determinants of early outcome after neonatal cardiac surgery in a developing country. J Thorac Cardiovasc Surg 2007;134:765-71.

22. Sinzobahamvya N, Arenz C, Brecher AM, Urban AE. Atrial isomerism: A surgical experience. Cardiovasc Surg 1999;7:436-42.

23. Choudhary SK, Bhan A, Sharma R, Mathur A, Airan B, Saxena A, et al. Repair of total anomalous pulmonary venous connection in infancy: Experience from a developing country. Ann Thorac Surg 1999;68:155-9.

24. Sivakumar K, Shivaprakasha K, Rao SG, Kumar RK. Operative outcome and intermediate follow-up of neonatal Blalock-Taussig shunts. Indian Heart J 2001;53:66-70.

25. Jacobs JP, Mavroudis C, Jacobs ML, Lacour-Gayet FG, Tchervenkov Cl, William Gaynor J, et al. Lessons learned from the data analysis of the second harvest (1998-2001) of the Society of Thoracic Surgeons (STS) Congenital Heart Surgery Database. Eur J Cardiothorac Surg 2004;26:18-37.

26. Health Transformation Program in Turkey. Progress report. January 2009. Ministry of Health. [database on the Internet]. 2009. Available from:www.tusak.saglik.gov.tr/pdf/kitaplar/TurkeySPDEng.pdf.

27. T.C. Sağlık Bakanlığı. Temel Sağlık Hizmetleri Genel Müdürlüğü. Türkiye Kalp ve Damar Hastaliklarini Önleme ve Kontrol Programi Birincil, İkincil ve Üçüncül Korumaya Yönelik Stratejik Plan ve Eylem Planı (2010-2014), Ankara: 2010. Yayın no: 812. http://www. aydinhsm.gov.tr/upload/files/kronik/kdhokpeylemplani.pdf

28. T.C. Sağlık Bakanlığı Tedavi Hizmetleri Genel Müdürlüğü. Türkiye'de özellikle planlama gerektiren sağlık hizmetleri. Ankara: 2011. Yayın no: 836. http://www.tkhk.gov.tr/Eklenti/351,turkiyede-Ozellikliplanlama-gerektiren-saglik hizmetle-.pdf? 